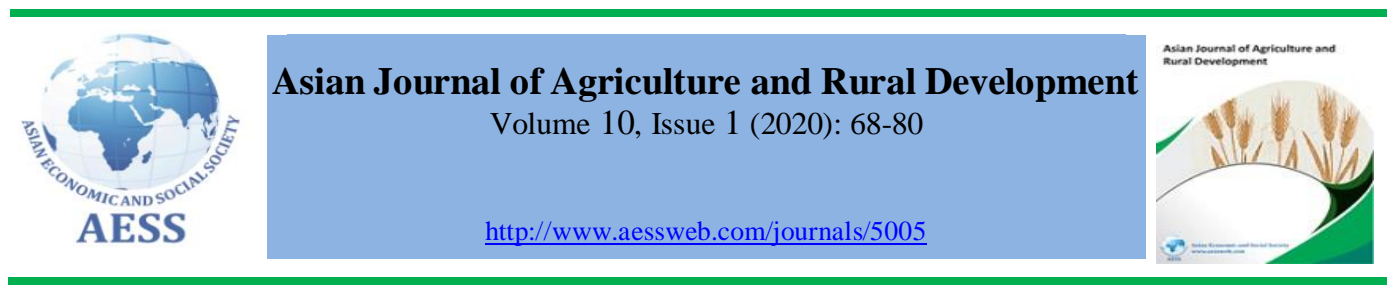

\title{
TRANSACTION COST, PRICE RISK PERSPECTIVE AND MARKETING CHANNEL DECISION OF SMALL-SCALE CHILI FARMERS IN TRA VINH PROVINCE, VIETNAM
}

\section{Pham Quoc Hung a \\ Huynh Viet Khai ${ }^{\text {b }}$ i}

\section{ARTICLE HISTORY:}

Received: 23-Sep-2019

Accepted: 24-Feb-2020

Online Available: 09-Mar2020

\section{Keywords: \\ Marketing channel, \\ Chili, \\ Outlet references, \\ Risk, \\ Probit model}

${ }^{a}$ Department of Agricultural Economics, College of Economics, Can Tho University, Vietnam

${ }^{\mathrm{b}}$ Department of Environmental and Resource Economics, College of Economics, Can Tho University, Vietnam

\section{\.}

\section{Contribution/ Originality}

The choice of marketing channel is one of the main decisions for producers because different channels are characterized by certain levels of profitability and cost. The study aims to identify factors affecting the chili farmer's selection of a distribution channel. The results of this study could provide policymakers useful information to master chili farmers' distribution channels.

DOI: $10.18488 /$ journal.1005/2020.10.1/1005.1.68.80

ISSN (P): 2304-1455/ISSN (E):2224-4433

How to cite: Pham Quoc Hung and Huynh Viet Khai (2020). Transaction cost, price risk perspective and marketing channel decision of small-scale chili farmers in Tra Vinh Province, Vietnam. Asian Journal of Agriculture and Rural Development, 10(1), 68-80. 


\section{INTRODUCTION}

The Vietnamese government is encouraging rice farmers in the Mekong Delta to diversify their crops by cultivation other productive crops such as fruit and vegetable on the land that is under productive. The reason for this change is relatively low rice production in the Mekong delta; one of the two main agricultural production areas in Vietnam, is increasingly at risk due to land degradation of triple-crop rice cultivation and the adverse impact of climate change in the region. Under the promotion campaign, the rice-growing area has been reduced by 14,000 ha over the period 2010 to 2014 (yearly reduction of $0.18 \%$ ) and fruit and vegetable production increase from 1.54 million ha in 2014 to 1.72 million ha in 2016. This causes the fruit and vegetable sector to be one of the main income sources for many farmers in the region and contribute to a high portion of Vietnamese agriculture export value. One of the vegetables promoted for cultivation in the Mekong Delta under this program is export-oriented chili which is increasing sharply in recent years due to high export demand. However, chili farmers have been confronted with many difficulties relating to market their products and obtaining a profitable price because of the small-scale production and poor integration. Furthermore, dependent on the dominated intermediaries to market chili makes farmers face more risk and affect farmers' income sustainability.

Marketing was considered to play a vital role to reduce poverty and promote sustainability in agriculture in developing countries like Vietnam. However, a high transaction cost is especially a major marketing constraint (Woldie and Nuppenau, 2009) and is one of the most important causes for small-scale farmer's failure to join the market (Ouma et al., 2010). Furthermore, the limitations of small-scale farmers are poor infrastructure, distance from the market and inadequate information with respect to market their product. Small-scale production and lack of bargaining power make farmers to be exploited by dominated traders; as a result, small-scale farmers become price takers. Particularly, perishable products force the farmer to sell soon after harvesting due to high cost of the storage facility. Thus, it is trouble for farmers to obtain a fair price when they market their products to brokers or collectors at the farm gate. As a consequence, choice of marketing channel is one of the main decisions for farmers since various channels are described by certain levels of profitability and cost. Therefore, mastering the determinants of the marketing channel selection is essential not only for the improvement of marketing channels but also for an increase in farmer's income (Soe et al., 2015).

The choice of distribution channel is part of the ways for a farmer to obtain marketing objectives with their marketing strategy. Generally, there are many studies about chili in Mekong Delta such as chili farmer performance and chili value chain, but few studies on farmer's marketing strategy selection. Although chili farmers in the Mekong Delta have many choices to market for their products such as selling to local traders or wholesalers, the current cooperative channel is expected to be a suitable choice to overcome the drawbacks of small-scale production. However, knowing the factors drive chili farmers' decision to participate in different marketing channels should be clarified before making any encouraging policies. The aim of the study is to determine factors affecting the chili farmer's selection of a distribution channel. The results of this study could provide policymakers useful information to master chili farmers' distribution channels.

\section{LITERATURE REVIEW}

An investigation of the marketing channel decision was conducted by many authors and studies follow two main streams, transaction cost theory and decision-making process or farmer behavior. Transaction costs are defined as costs existed in the process of an exchange and are categorized into fixed and variable transaction costs (Woldie and Nuppenau, 2009). Transaction costs were existed before and after the actual exchange. Fixed transaction costs are invariant to the volume of output traded and may include the costs of searching for a partner to exchange a product, screening potential trading partners to ascertain their credibility, bargaining with potential trading partners to 
reach an agreement, monitoring the agreement to ensure that its conditions are fulfilled, and enforcing the exchange agreement. Proportional or variable transaction costs, on the other hand, include the costs of transferring the product such as transportation costs and time spent to deliver the products to the market. According to Mmbando et al. (2015) transaction costs are largely unobserved and cannot be easily recorded or measured directly in a survey and transaction cost theory is seen as a viable means of explaining the acquisition decision in marketing channels (Chen et al., 2006).

Many studies found that transaction costs, farmers' characteristics and also farmers' risk perspective influenced smallholders' decisions such as choices between alternative marketing options (Higuchi et al., 2012; Mabuza et al., 2014; Siddique et al., 2017; Woldie and Nuppenau 2009; Xaba and Masuku 2012) and market participation (Alene et al., 2008; Jagwe et al., 2010; Mmbando et al., 2015; Ouma et al., 2010). Regarding marketing channel selection, studies of Woldie and Nuppenau (2009) found that transaction cost such as the cost of information, negotiation, and monitoring and enforcement plays an important role to identify farmers' marketing channel choice decision among selling to village retailers, wholesale traders and cooperative marketing group because transactions costs are different in these alternative channels. This study revealed that small land households prefer cooperative channels whereas larger farm households, having more bargaining power, normally face lower transaction costs prefer wholesale traders. Farmers who receive market information easily prefer selling their products in the private market to through cooperative. If it takes more time to transact with wholesale traders, farmers are more likely to sell through the cooperative. This is similar to the finding of Jagwe and Machethe (2011), and Mabuza et al. (2014) about banana and mushroom growers, stating that geographical location and access to price information significantly affect the choice of selling point, so mainly access to the price information from village mates and neighbors enhance the chance to sell at farm gate rather than travel to the market to sell their product.

Transaction cost was also found to influence farmers' choice of marketing channels in studies by Boger (2001) and Gong et al. (2006) on cattle and hog sectors. In the study by Gong et al. (2006), the spot market was still the main selection by farmers with 36 percent of farmers selling cattle through this channel. Twenty-two percent sold via a dealer and 15 percent choose to sell directly to processors. This study also suggested that the farmers who are willing to pay higher transaction costs such as negotiation and monitoring costs are more likely to sell directly to the processor. It means that a more specialized farm would be more likely to sell directly to the processor. Furthermore, payment delay and grade uncertainty not only occur for farmers who sell cattle to the processor but also farmers still choose this channel because of the premium bonus. Bargaining power is measured by the herd size and the higher the bargaining power of the farmers, the more likely the farmer is to sell directly to the processor. In contrast, farmers who have a few cattle and relatively low bargaining power tend to use the spot market and middlemen. In addition to these above transaction costs, Boger (2001) also found that the type of contract affects a farmer's choice to sell hog to large processors or to traders and local slaughterhouses. In addition, the delay when produce is sold and when payment is made is an important negotiation cost that influences the choice of marketing channel by cocoa farmers. Transportation cost gets higher related to an increase in distance from the farm and the bad condition of the road, and so farmers could not completely avoid it (Ogunleye and Oladeji, 2007).

Studies based on farmer's behavior investigated the factors influencing farmer's marketing channel selection focused more on household characteristics and the findings are different depending on the produce. Social characteristics are found by Higuchi et al. (2012) to be effective in predicting a farmer's marketing choice and the effect is different basing on a specific sector. The study results reveal that older and married coffee farmers are likely to participate in a cooperative channel, whereas large member household tends to commercialize through intermediaries. In the same viewpoint, Gong et al. (2006) show that farmers favoring processor channels are those who have 
high education and more investment. More experienced farmers, however, tend to participate in the spot market. In contrast, Safi et al. (2018) found that experience farmers choose the processor channel due to the complex technique of semi processing in the grape sector. Moreover, expertise on grade and standard, contractual agreement, social capital, market infrastructure, group participation are factors affecting household marketing behavior (Jari and Fraser, 2009).

In addition, the study of Soe et al. (2015) show that the farmers who possess storage, transportation, and larger quantity are more likely to engage in direct marketing channel to rice mills. This study emphasizes the important role of forming the farmers' cooperative because individual marketing practices expose farmers to high transaction costs with low bargaining power. Other research found that although a farmer can choose a single outlet or a combination of outlets during the fish production season, the wholesale channel was the most commonly used in $64.2 \%$ of the survey sample in the study of the Louisiana Crawfish Industry. Larger farmers were found to be more likely to market via retail outlets, farmers having come from off-farm sources and holding a college degree increased the probability of marketing via a wholesaler (Nyaupane and Gillespie, 2010). A middlemen marketing channel is preferred to cooperative by cocoa farmers because of the prompt payment, payment by cash, no distance covered to sell and no transportation cost (Ogunleye and Oladeji, 2007). Furthermore, cooperatives are often seen as a way to increase farmers' bargaining power within the food chain. More presence of processor or trader signals a high degree of competition between these intermediaries which reduces the need for farmers to deliver to cooperative and hence increase the likelihood of spot market solution. It also means that the fewer alternative is present for delivering an agricultural product the more likely farmers are to join a cooperative as a member and also deliver to that cooperative (Pascucci et al., 2011). Similarly, trust in cooperative leadership and cooperatives' payment system was also found to affect the coffee farmer's marketing channel choice decision (Milford, 2014).

Risk is also another factor affecting farmer's marketing channel choice decisions. Few studies focus on this variable because it is difficult to quantify in the survey, particularly at the farmer level. Besides, other normal risks link weather and pest, the marketing channel also provides producer marketing risks. Price risk due to the competition of other farms and other channels is playing an important role in farmer's marketing channel selection (LeRoux et al., 2010). The study by De Bruyn et al. (2001) also reveals the relationship between price uncertainty and farmer's choice of selling cattle to state owed abattoirs or the indigenous market. Furthermore, cooperative is found to offer stable price and cooperative suppliers are more risk-averse in comparison to those dealing with traders in the spot market (Mujawamariya et al., 2013).

\section{DATA AND ANALYSIS METHOD}

A structured questionnaire was used to collect data randomly with a sample of 193 farmers in Tra Vinh province where farmers are encouraged to participate in the cooperative channel. These farmers were interviewed face to face about transaction costs, household's risk perception and risk attitudes, social-economic factors such as on-farm and off-farm activities, especially information on chili production and marketing. Farmers were asked to list all buyers that they sold chili to and the percentage of chili production sold to each buyer. Chili farmers may face several risks, but market risk or price fluctuation is of most concern. The perception of price risks is measured following the study of Saqib et al. (2016) by using a 5-points Likert scale, from 1 (very low) to 5 (very high). The responses of farmers then were put into a risk matrix to measure individual price risk perception (See Figure 1). 


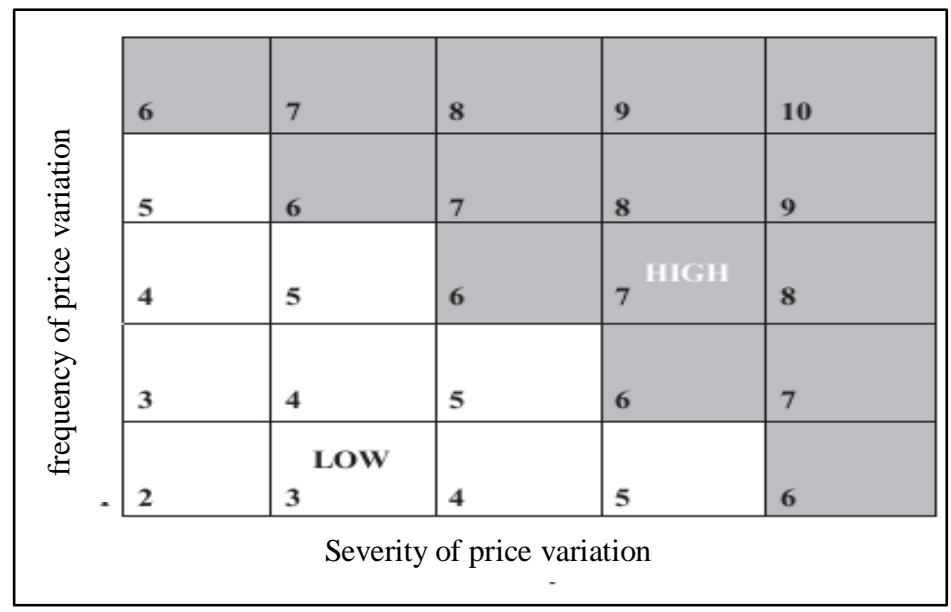

Figure 1: Risk matrix

Source: Saqib et al. (2016)

Regarding risk attitude, there are several methods to quantify farmers' risk attitudes. Quantify risk attitudes using game and econometric are reliable, but these methods are very difficult to conduct in the survey. This study used a simple approach following the study of Tu and Bulte (2010) by a simple survey question. We asked respondents to indicate, on a 10 point-scale, whether they agreed with the statement: "I don't dare to plant a new type of chili seedling as the first person in my village because I think it's too risky." Hence, a larger score is associated with more risk aversion. We also have some discussions with the relevant stakeholders of chili supply chain to clarify the distribution system. Farmers could sell their product to local trader, wholesalers, and cooperative. Farmers who sell to cooperative usually have an advanced verbal agreement. Under this agreement, farmers receive input supply service such as seedling, fertilizer and pesticide in credit and in return farmers commit to grow seedling provided by the cooperative and strictly follow the growing plan set by the cooperative because of quality management. Cooperative in return, has the obligation to buy all farmers' produce at the harvest time. Farmers, however, have the right but not the obligation to sell to the cooperative. Wholesalers just buy small quantity directly from the farmers to update the market price because of high transaction cost. Therefore, in this study we focus more on cooperative as an innovative channel that could help farmers overcome their small-scale constraint and classify farmers in to two channels, cooperative channel for farmers who sell chili to cooperative and traditional channel for those who sell to other outlets.

We use a Probit model for the regression determining market channel choice between the cooperative channel and the traditional channel. The Probit model takes the form:

$$
\operatorname{Prob}(\mathrm{y}=1 \mid \mathrm{X})=\int_{-\infty}^{X^{\prime} \beta} \emptyset(v) d v=\varnothing X^{\prime} \beta
$$

where $\emptyset(v)$ represents the standard normal probability distribution. This model measures the producer's probability of participation in the cooperative channel taking into consideration the transaction cost, risk and producer's characteristics:

$$
\operatorname{Prob}\left(y_{i}=1 \mid X\right)=\beta_{0}+\beta_{1} X_{1}+\cdots+\beta_{i} X_{i}+\varepsilon_{i}
$$

where $y$ represents the market channel to which the producer sells, with $y=0$ for the producers who sell to the traditional channel, and $y=1$ for the producers who sell to the cooperative 
channel., $i$ is the number of independent variables, $\beta_{i}$ is the beta coefficient, and $\varepsilon_{i}$ is a random error term, $X_{i}$ is a vector of selected explanatory variables that are proxy for transaction cost, risk perspective, and farmer's characteristics.

\section{VARIABLES DEFINITION AND DESCRIPTIVE ANALYSIS}

Table 1: Definition and summary statistic of selected variables

\begin{tabular}{llc}
\hline Variables & \multicolumn{1}{c}{ Definition } & $\begin{array}{c}\text { Freq. \% } \\
\text { (mean) }\end{array}$ \\
\hline Searching information & 40.93 \\
Market info & 1 if the household head knows price in the local market & 38.34 \\
Info-benefit & 1 if collected market information really benefit the exchange & 41.45 \\
Smartphone & 1 if household own smartphone, 0 otherwise & 75.13 \\
Negotiation and bargaining & $(4.97)$ \\
Setting price & 1 if buyers are those who set buying price, 0 otherwise \\
Distance to road & Distance from farm to main road (kilometre) & $(2.25)$ \\
No. of traders & Number of traders that farmer know & $(28.04)$ \\
Relationship & Duration of relationship with current buyer (months) & 39.90 \\
Selling pressure & 1 if household face pressure to sell right after harvest for cash & \\
Monitoring cost & & 29.02 \\
Uncertainty & 1 if household choose buyer because of less quality uncertainty & 64.25 \\
Repetition trade & 1 if household sell chili to the same buyer in previous crop & 47.15 \\
Agreement & 1 if household has oral selling agreement in advance with coop & \\
Risk perspective & & 85.49 \\
Risk perception & 1 if household head has high risk perception, 0 otherwise \\
Risk attitude & 10 -point scale, a larger score is more risk aversion & $(6.32)$ \\
Household and social economics characteristics & 67.88 \\
Gender & 1 if male household's head, 0 otherwise & $(5.48)$ \\
Education & Educational level of household head in years & $(3.03)$ \\
Experience & Number of years engaged in chili production & $(0.33)$ \\
Farmland & Chili farmland owned by household (ha) & $(3.87)$ \\
Ext contact & Number of attending agricultural extension within 3 years & 58.03 \\
Farm group & 1 if member of common goal group, 0 otherwise & 57.51 \\
Membership & 1 if household know someone who is cooperative membership & 52.37 \\
Seed coop & 1 if household buy seed from cooperative, 0 otherwise \\
Off-farm & 1 if household has other earning activity, 0 otherwise & 32.16 \\
\hline
\end{tabular}

Source: Based on authors' own survey, 2018

Transaction cost variables were collected by interviewing chili farmers through a list of questions about the constraints of a marketing channel such as the costs of looking for information, negotiation and bargaining, and monitoring. Market risk perspective and household characteristics was also considered in the analysis model. In the sample, there are about $50.26 \%$ choosing a cooperative channel and $49.74 \%$ selling through a traditional channel. The variable definition and descriptive statistics of the selected variables are summarized in Table 1.

Searching information costs are costs incurred before the transaction. This is a common practice by farmers to gather some sort of price information and this is not free of charge (Woldie and Nuppenau, 2011). In this study, the cost is calculated by the action of searching for a market price before farmers selling their produce. Prior to making any exchange, producers need to search for information such as price and buyers. Farmers in the survey area were asked if they search for a price in advance as knowing the market price in advance influence the selection of trading partners. Information searching cost is also measured by looking at if this collected information benefits 
farmers in their transactions. This emphasizes the reliability of the information source and it may take considerable time in searching for reliable information because it is sometimes easy for some households to find such information, while it could be difficult for others. It is also argued that trustworthy information will help farmers select the appropriate outlet and have enough information to deal with a better price (Negi et al., 2018). The hypothesis is that when knowing the market price and having reliable market information, farmers are likely to deal with traders who come to buy farmers' produce directly at the farm gate and as the exchange is more flexible compared to deal with a cooperative. The statistical results show that more than 40 percent of the respondents said that they know the buying price in the local market before selling their produce, while about 38 percent confirm the benefit of the searched information. Moreover, having a smart phone is also a way of searching for market information in the modern era and is also expected to affect outlets selection by farmers. Access to the Internet has increasingly become more popular in rural Vietnam, owning a smart phone increase the chance for the farmer to obtain market information, hence reduce the transaction cost through reaching the final transaction quickly. Access to information also improve bargaining power which could encourage farmers to participate in the traditional channel because of expected advantageous exchange that it brings to farmers through having strong bargaining power. Table 1 show that almost 42 per cent farmers in the survey sample owned smart phone which helps them to connect to the Internet and look for up-to date market information. Farmers could not only decide where and which price to sell their products but also decrease the searching costs to get the best deal.

Negotiation and bargaining costs are costs incurred during the transaction. These costs may be very important when there is imperfect information regarding price (Alene et al., 2008). Having the power to influence the setting of exchange price in the exchange agreement refers to bargaining power which was reviewed by Mabuza et al. (2014), who found that farmers would supply their commodity through a channel where they have a better bargaining position. Table 1 show that the bargaining power of most of the farmers is very weak because 75 percent said that the buyer is the one who set the exchange price. Another important factor is the costs of transporting farm products from the farm to the main road, as chili farmers usually do the selling exchange at the place (side road) where buyers' truck can reach to collect chili. Therefore, living far from the main road could prevent farmers from transporting their product to the exchange place where cooperative can use the truck to collect farmers' produce, so the distance to the road is expected to influence negatively the choice of cooperative channel. The information from the survey shows that the average distance from farmers to the road is about 5 kilometres. This could be a barrier for the farmer access to the reliable buyer like a cooperative. In addition, several traders that farmer know is related to market competition through the presence of the local traders in the market at harvest time. More traders present in the market reflect how hard the competition is and improve the opportunity for farmers to have an effective deal, whereas the monopoly due to less presence of traders may lead to increasing opportunistic behavior, hence increase the transaction cost. As a result, it is expected that more traders that the farmer knows the market, the less they chose to sell products through the cooperative channel.

The survey reveals that each farmer knows about two traders in the region. This, on the one hand, could imply that farmers have more options to sell their product but on the other hand less presence of traders could also reflect the likelihood of selecting the cooperative channel. In addition, the duration of the relationship with the cooperative is expected to encourage farmers' commitment to this channel. Because it is revealed that the length of the relationship also reflects the trust between buyers and sellers, the longer the relationship is the less time that farmers spent to obtain the exchanges, hence reduce the transaction cost through timesaving. In fact, farmers in the survey area have a rather long relationship with their buyers with an average of about 28 months, which is long enough for them to stay in the settled relationship, another factor that can influence the channel. 
Monitoring costs are a cost incurred after the transaction. These costs are mainly incurred when the seller seeks to enforce and monitor the payment, and other advanced agreement. The monitoring cost is incurred when farmers spend time to manage farming to meet the required quality and manage the payment from the buyer for their produce. These costs arise when the time increases. In the survey area, farmers would face grade uncertainty when selling directly to cooperative as farmers would monitor farm to obtain the product quality stipulated by the cooperative, but the grade would not be known until the chili has been harvested. Farmers get the payment based on a final grade result, creating risks for them. Therefore, more farmers want to sell their products on the spot market if the grade uncertainty is higher. In addition, while there are currently no formal quality standards for a traded chili in Vietnam, buyers generally screen delivered chili for quality based on visual inspection. If the producer faces quality uncertainty, they are more likely to sell their chili through a channel with no stringent quality requirements. The other variables in this category are repetitive trade. Repetition trade expresses trust in buyers that could help the farmer to do a smooth transaction and decrease transaction costs. Trust in cooperative could allow lower transaction costs because farmers will not need to obtain information for recognizing the reliability of this buyer. This leads to the expectation that the repetition of trade with cooperative will retain farmers in the cooperative channel. Moreover, having selling agreement in advanced is expected to have an influence on farmers' decision to engage in the cooperative channel as argued by Woldie and Nuppenau (2009) that trade agreement will help the farmers in keeping track of the transaction and also to counteract any conflicts, hence this will minimize monitoring cost. The statistical results reveal that about 29 percent replied that they were concerned about quality uncertainty when selecting buyers, almost 64 percent selling chili to the same buyer in the previous crop and about 47 percent have informal advanced selling agreement.

In terms of risk perspective which is measured by price risk perception and risk attitude. The descriptive statistics show that farmers have high-risk perception with almost 86 percent, and they are a bit more risk-averse with a score of more than 6 points. Regarding the household characteristic, according to Cuevas (2014), female farmers have more various transaction costs (accessing land and credit) than male ones. Farming experience and education considered as a human capital could help farmers to get market information to decrease transaction costs. Moreover, social networks and organizational membership decrease transaction costs since they could make sure to cooperate among farmers to use scarce community resources. Therefore, the household characteristic is also expected to have an influence on household outlet choice. Our statistical results show that household heads are dominated by males with more than 67 percent and farmers, in general, having low education levels with an average of 5.4 school years. This is the current state in rural agriculture of Vietnam and this could affect the ability of negotiation, farm management and the transfer of production technology in the survey region. Farm experience regarding chili growing in the survey region is also low with an average of about 3 years. The average farmland area is around $0.3 \mathrm{ha}$ each and extension service is not an attractive activity in the survey area with an average of 3 times within 3 years. More than 57 percent of farmers engage in farm group and a similar rate was observed for knowing someone in the village who has cooperative membership. This illustrates that farmers in the region try to widen their network in agricultural production and cooperative is becoming a popular channel in the survey area. The statistical results also show that about 52 percent of farmers buying chili seedling from cooperative. The dependence on input services like buying input (seedling) on credit from cooperative may affect the negotiation of farmers when selling a product to the buyer who is farmers' input suppliers. As found by Tefera (2014) producers and buyers also intermingle in the credit market because the buyers supply credit to producers as the latter is expected to deliver their produces to them and this locked-in exchange could help farmers to save time looking for the buyers, hence reduce the transaction costs and keep farmers in the cooperative channel as the interdependence relationship. Finally, over 32 percent have income-earning activities other than producing chili. This would reflect the fact that farmers in the survey region diversify their income source which is an advantage and encourage farmers to be confident in making a chili marketing strategy. 


\section{RESULTS AND DISCUSSION}

The estimated coefficients and their marginal effects are presented in Table 2. The estimated parameters of the Probit model show the directions and reveal the likelihood of farmers' selections of the cooperative channel relative to the basic outcome of the traditional channel. However, the parameters estimated from the Probit model may be difficult to interpret because they are relative numbers to the outcome and just show the direction. The best way to study the effect of a unit change on the outcome would be to measure the marginal effect.

The estimated results indicate that searching for information costs affects the farmer's choice of marketing channel. The coefficients of market information and smart phone variables are statistically significant at the 5\% and $10 \%$ level respectively revealing that farmers who look for the market information before selling and those who own a smart phone are likely to prefer a cooperative channel. Particularly, farmers who know the selling price in the local market and those who possess a smart phone have 26 and 37 percent more likely to join the cooperatives channel compared to the households who do not know the local market price and possess the phone respectively. This finding indicates that access to information could strengthen farmers' bargaining power and enhance transactions with traders by reducing the search cost only in a single exchange. However, farmers prefer selling through the cooperative channel because farmers consider this channel a safer choice and would bring sustainable profit to farmers in the long term by offering a stable price. Regarding negotiation and bargaining cost, the coefficient of both numbers of trader and relationship variables are significant at 5\% level but a negative sign for the number of trader variable show that if farmers know one more trader, the probability of choosing cooperative channel would decrease $6 \%$. This is consistent with the study of Maina et al. (2015) that farmers do not consume a lot of hours searching for the buyer because they are readily available in the market.

In addition, having one more month relationship with the cooperative would increase the probability of participating in this channel by $0.7 \%$. This finding implies that a sustained relationship with the cooperative decreases the costs of negotiating a sale, hence encouraging farmers to remain in such a relationship. Furthermore, the probability of selling through the cooperative channel is $23 \%$ higher for those farmers who face selling pressure at the harvest time. This is the opposite of our expectation but might be explained that cooperative does not always seek self-interest but also for the mutual benefit of its members as well as the community. Particularly, cooperative not only pay cash as a trader but also provide a safe exchange as its legally registered trading location increases the trust to farmers in making the selling transaction. The study results show that no variables measuring monitoring costs are significant. This is inconsistent with the arguments of previous studies (Gong et al., 2006; Mabuza et al., 2014) that the more producers become concerned about meeting buyers' quality requirements, the less probability they will sell products to that channel. The negatively insignificant coefficient for quality uncertainty, however, could be explained that farmers would face quality uncertainty when selling chili to cooperative, but the safe exchange available through cooperative may not outweigh the quality uncertainty. Similarly, the negative sign of the coefficient of agreement variable could reflect the fact that farmers may not commit to the informal verbal agreement with the cooperative. The possible justification behind this deriving from our survey is that cooperative although promising a flooring price in a depressed market, only first-grade products are applicable. However, when the market price is rising, the price offered by the cooperative is always lower than the market price, hence this may affect the farmers' willingness to engage in such an agreement. 
Table 2: Factors determining chili farmer's choice marketing channel using Probit model

\begin{tabular}{|c|c|c|c|c|}
\hline \multirow{2}{*}{ Variables } & \multicolumn{2}{|c|}{ Probit model } & \multicolumn{2}{|c|}{ Probit marginal effect } \\
\hline & Coefficient & S.E. & $\mathrm{dy} / \mathrm{dx}$ & S.E. \\
\hline \multicolumn{5}{|c|}{ Searching information } \\
\hline Market info & $0.673 *$ & 0.350 & $0.263 * *$ & 0.131 \\
\hline Info-benefit & 0.453 & 0.415 & 0.179 & 0.161 \\
\hline Smartphone & $0.966^{* *}$ & 0.428 & $0.370 * *$ & 0.151 \\
\hline \multicolumn{5}{|c|}{ Negotiation and bargaining } \\
\hline Setting price & 0.223 & 0.387 & 0.088 & 0.151 \\
\hline Distance to road & 0.040 & 0.045 & 0.016 & 0.018 \\
\hline No. traders & $-0.166^{* *}$ & 0.078 & $-0.066^{* *}$ & 0.031 \\
\hline Relationship & $0.019 * *$ & 0.009 & $0.007 * *$ & 0.003 \\
\hline Selling pressure & $0.602 *$ & 0.342 & $0.236^{*}$ & 0.130 \\
\hline \multicolumn{5}{|l|}{ Monitoring cost } \\
\hline Uncertainty & -0.287 & 0.369 & -0.113 & 0.144 \\
\hline Repetition trade & 0.150 & 0.347 & 0.059 & 0.137 \\
\hline Agreement & -0.241 & 0.357 & -0.961 & 0.141 \\
\hline \multicolumn{5}{|l|}{ Risk perspective } \\
\hline Risk perception & -0.243 & 0.498 & -0.096 & 0.196 \\
\hline Risk attitude & $0.081 *$ & 0.049 & $0.032 *$ & 0.019 \\
\hline \multicolumn{5}{|c|}{ Household and social economics characteristics } \\
\hline Gender & 0.575 & 0.356 & $0.224 *$ & 0.133 \\
\hline Education & 0.025 & 0.051 & 0.010 & 0.020 \\
\hline Experience & 0.135 & 0.158 & 0.053 & 0.063 \\
\hline Farmland & -0.000 & 0.000 & -0.000 & 0.000 \\
\hline Ext. contact & 0.028 & 0.058 & 0.011 & 0.023 \\
\hline Farm group & $0.904 * *$ & 0.353 & $0.346^{* * *}$ & 0.125 \\
\hline Membership & $1.257 * * *$ & 0.379 & $0.466 * * *$ & 0.121 \\
\hline Seed coop & $2.320 * * *$ & 0.454 & $0.750 * * *$ & 0.092 \\
\hline Off-farm & $0.624 *$ & 0.337 & $0.244^{*}$ & 0.127 \\
\hline Chi-square $\chi 2$ test & $170.16^{* * *}$ & & & \\
\hline Pseudo R2 & 63.60 & & & \\
\hline Log-likelihood & -48.63 & & & \\
\hline
\end{tabular}

Notes: $* * *, * *$ and $*$ significant at $1 \%, 5 \%$ and $10 \%$ level of significance respectively.

Source: Based on authors' own survey, 2018

Risk perspective is measured by two variables but only the estimated coefficient of risk attitude is significant at a $10 \%$ level. This result implies that more risk-averse farmers are likely to participate in the cooperative channel. This is in line with Zheng et al. (2012) who found that farmers will participate in a cooperative channel if their perceived risk is high. In terms of farmer's characteristics, the estimated results show that farmers who have farm groups' membership are more likely to prefer cooperative marketing channels as opposed to traditional channel for their produce and the probability of selling through cooperative channel is $34 \%$ and $46 \%$ higher for those farmers who joining farm group and knowing cooperative's membership respectively. This also indicates that enlarging network through farm groups' membership would provide farmers with more chance to engage in the cooperative channel because they are confident in making a decision basing on shared information from the network, consistent with the study by Jagwe et al. (2010). The variable of the seed coop is significant at a $1 \%$ level, indicating that farmers buying seedling from cooperative have a $75 \%$ higher probability to choose the cooperative channel. It also means that farmers may be locked-in by credit advances to buy inputs such as seedling and fertilizer. Such arrangements could result in retaining farmers in the relationship with the buyer in the output market at harvest time or households sell chili to cooperative due to an interlocked exchange. 
Finally, the result also supports the argument that diversifying the earning activity increase the chance to participate in the cooperative channel.

\section{CONCLUSION}

This paper seeks to explore the factors that influence small-scale chili farmers' choice of marketing channels when chili is considered to be one of the vegetables promoted for cultivation in the Mekong Delta due to the adverse impacted of climate change in the survey area and increasing demand for export-oriented chili in recent years. Particularly, because the cooperative channel is currently supposed to be a suitable choice for overcoming the constraints of small-scale production. Using transaction cost economics as the main theoretical framework, we employ the Probit model to estimate the determinants of marketing channel based on field survey data collected among 193 chili farming households in Tra Vinh province in Vietnam. The survey reveals that farmers mainly sell their products through cooperative channels and traditional channels (local traders). The statistical results show that in the survey sample, the cooperative channel has become a more popular channel with around $50.26 \%$ of farmers choosing this outlet whereas $49.74 \%$ selling through the customary channel. There is a high rate of smart phone ownership by farmers which can be used to search for market information, whereas the education level of farmers in the survey area is low. Farmers are more risk-averse and diversify their earning activities for income sustainability.

The estimated Probit results show that the marketing choice decision of chili farmers is influenced by transaction costs, price risk attitude and farmers' characteristics. Searching for pricing information before selling increases the probability of choosing the cooperative channel. In addition, cooperative use seedling supply as an interlocked exchange to retain farmers in the cooperative channel. The cooperative channel is also found to not only be the preferred channel when farmers are confronted with selling pressure due to the perishable nature of the chili but also is a safe channel for more risk-averse farmers. However, the field survey also reveals the limitation of keeping a promise to fulfil the purchasing agreement coming from both farmers and cooperative due to the conflict in pricing the product under the advanced agreement at the time of selling. Based on the research results, we recommend that cooperative should take the leadership role in fulfilling its commitment and making sure that cooperative should be an appropriate channel helping smallscale farmers to overcome the market constraint and effectively implement a market participation strategy to sustain farmers' income. Although applying transaction costs as a primary analytical framework, this study just examines the determinants of outlet choice, particularly focusing on the cooperative channel in the transition economies context like Vietnam where cooperative mainly takes the role of input services suppliers. There are just a few cooperatives considering marketing function as an integral part of a cooperative governance structure. There is need of further research on this field to clarify this issue and contribute more to the marketing channel choice literature as well as overcome this limitation of our study.

\footnotetext{
Funding: This study is funded in part by the Can Tho University Improvement Project VN14-P6, supported by a Japanese ODA loan.

Competing Interests: The authors declared that they have no conflict of interests.

Contributors/Acknowledgement: All authors equally contributed to the article.

Views and opinions expressed in this study are the views and opinions of the authors, Asian Journal of Agriculture and Rural Development shall not be responsible or answerable for any loss, damage or liability etc. caused in relation to/arising out of the use of the content.
} 


\section{References}

Alene, A. D., Manyong, V. M., Omanya, G., Mignouna, H. D., Bokanga, M., \& Odhiambo, G. (2008). Smallholder market participation under transaction costs: Maize supply and fertilizer demand in Kenya. Food Policy 33, 318-328. https://doi.org/10.1016/j.foodpol.2007.12.001.

Boger, S. (2001). Quality and contractual choice: a transaction cost approach to the Polish hog market. European Review of Agricultural Economics, 28, 241-262.

Chen, M. S., Chang, H. J., Huang, C. W., \& Liao, C. N. (2006). Channel coordination and transaction cost: A game-theoretic analysis. Industrial Marketing Management, 35, 178-190. https://doi.org/10.1016/j.indmarman.2005.03.007.

Cuevas, A. C. (2014). Transaction costs of exchange in agriculture: a survey. Asian Journal of Agriculture and Development, 11, 21-38.

De Bruyn, P., De Bruyn, J. N., Vink, N., \& Kirsten, J. F. (2001). How transaction costs influence cattle marketing decisions in the northern communal areas of Namibia. Agrekon, 40, 405425.

Gong, W., Parton, K., Cox, R. J., \& Zhou, Z. (2006). Transaction costs and cattle farmers' choice of marketing channels in China: A Tobit analysis. Management Research News, 30, 47-56. https://doi.org/10.1108/01409170710724296.

Higuchi, A., Moritaka, M., \& Fukuda, S. (2012). The impact of socio-economic characteristics on coffee farmers' marketing channel choice: evidence from villa Rica, Peru. Sustainable Agricultural Research, 1, 13-18.

Jagwe, J. N., \& Machethe, C. (2011). Effects of transaction costs on choice of selling point: a case of smallholder banana growers in the Great Lakes region of Central Africa. Agrekon, 50: $109-123$.

Jagwe, J. N., Machethe, C. L., \& Ouma, E. (2010). Transaction costs and smallholder farmers' participation in banana markets in the Great Lakes Region of Burundi, Rwanda and the Democratic Republic of Congo. African Journal of Agricultural and Resource Economics, 6 , 302-317.

Jari, B., \& Fraser, G. C. G., 2009. An analysis of institutional and technical factors influencing agricultural marketing amongst smallholder farmers in the Kat River Valley, Eastern Cape Province. African Journal of Agricultural Research, 4, 1129-1137.

LeRoux, M. N., Schmit, T. M., Roth, M., \& Streeter, D. H. (2010). Evaluating marketing channel options for small-scale fruit and vegetable producers. Renewable Agriculture and Food Systems 25, 16-23.

Mabuza, M. L., Ortmann, G., \& Wale, E. (2014). Effects of transaction costs on mushroom producers' choice of marketing channels: implications for access to agricultural markets in Swaziland. South African Journal of Economic and Management Sciences, 17, 01-13.

Maina, C. M., Lagat, J. K., \& Mutai, B. K. (2015). Effect of transaction costs on choice of mango marketing channel: the case of small scale farmers in Makueni County, Kenya. Journal of Agriculture and Veterinary Science, 8, 54-62.

Milford, A. B. (2014). Co-operative or coyote? Producers' choice between intermediary purchasers and Fairtrade and organic co-operatives in Chiapas. Agriculture and Human Values, 31, $577-591$.

Mmbando, F. E., Wale, E. Z., \& Baiyegunhi, L. J. (2015). Determinants of smallholder farmers' participation in maize and pigeonpea markets in Tanzania. Agrekon, 54, 96-119.

Mujawamariya, G., D’Haese, M., \& Speelman, S. (2013). Exploring double side-selling in cooperatives, case study of four coffee cooperatives in Rwanda. Food Policy, 39, 72-83.

Negi, D. S., Birthal, P. S., Roy, D., \& Khan, M. T. (2018). Farmers' choice of market channels and producer prices in India: Role of transportation and communication networks. Food Policy 81, 106-121. https://doi.org/10.1016/j.foodpol.2018.10.008.

Nyaupane, N. P., \& Gillespie, J. M. (2010). Factors influencing producers' marketing decisions in the Louisiana crawfish industry. Journal of Food Distribution Research, 42, 1-11. 
Ogunleye, K. Y., Oladeji, J. O. (2007). Choice of cocoa market channels among cocoa farmers in ila local government area of Osun state, Nigeria. Middle-East Journal of Scientific Research, $2,14-20$.

Ouma, E., Jagwe, J., Obare, G. A., \& Abele, S. (2010). Determinants of smallholder farmers' participation in banana markets in Central Africa: the role of transaction costs. Agricultural Economics, 41, 111-122. https://doi.org/10.1111/j.1574-0862.2009.00429.x.

Pascucci, S., Gardebroek, C., Dries, L. (2011). Some like to join, others to deliver: an econometric analysis of farmers' relationships with agricultural co-operatives. European Review of Agricultural Economics, 39, 51-74.

Safi, M. A., Amekawa, Y., Isoda, H., Hassanzoy, N., \& Ito, S. (2018). Cost-Benefit Efficiency and Factors Influencing Farmers' Choice of Marketing Channel in Grape Value Chain: Evidence from Kabul, Afghanistan. Journal of the Faculty of Agriculture Kyushu University, 63, 159168.

Saqib, S. E., Ahmad, M. M., Panezai, S., \& Ali, U. (2016). Factors influencing farmers' adoption of agricultural credit as a risk management strategy: The case of Pakistan. International Journal of Disaster Risk Reduction, 17, 67-76. https://doi.org/10.1016/j.ijdrr.2016.03.008.

Siddique, M. I., Garnevska, E., \& Marr, N. E. (2017). An Analysis of Marketing Channel Choice Decisions by Smallholder Citrus Growers. Australian Academy of Business and Economics Review, 1, 50-84.

Soe, W. P. P., Moritaka, M., \& Fukuda, S. (2015). An analysis of the factors influencing marketing channel choice by paddy rice farmers in Myanmar. Journal of the Faculty of Agriculture Kyushu University, 60, 535-542.

Tefera, T. (2014). Analysis of chickpea value chain and determinants of market options choice in selected districts of southern Ethiopia. Journal of Agricultural Science, 6, 26-40.

Tu, Q., \& Bulte, E. (2010). Trust, Market Participation and Economic Outcomes: Evidence from Rural China. World Development, 38, 1179-1190. https://doi.org/10.1016/j.worlddev.2009.12.014.

Woldie, G. A., \& Nuppenau, E. A. (2011). A contribution to transaction costs: evidence from banana markets in Ethiopia. Agribusiness, 27, 493-508.

Woldie, G. A., \& Nuppenau, E. A. (2009). Channel choice decision in the Ethiopian banana markets: A transaction cost economics perspective. Journal of Economic Theory, 3, 80-90.

Xaba, B. G., \& Masuku, M. B. (2012). Factors affecting the choice of marketing channel by vegetable farmers in Swaziland. Sustainable Agriculture Research, 2, 112-123.

Zheng, S., Wang, Z., \& Awokuse, T. O. (2012). Determinants of producers' participation in agricultural cooperatives: evidence from Northern China. Applied Economic Perspectives and Policy, 34, 167-186. 